\title{
Determining influential factors in the formation of environmental awareness of rural women: the case of Diyarbakır-Ergani, Turkey
}

\author{
Songül Akın ${ }^{1 *}$ (1) \\ ${ }^{1}$ Agricultural Economics Department, Faculty of Agricultural, Dicle University, 21280, Sur/Diyarbakır, Turkey. E-mail: sakin@dicle.edu.tr. \\ ${ }^{*}$ Corresponding author. \\ ABSTRACT: In this study, it is determined the factors that affect the environmental awareness of rural women, who constitute the other half of \\ the society and are intermingled with nature, which is a prerequisite for developing environmentally sensitive behaviors. The data of the study \\ were collected through face-to-face surveys in Ergani, the district with the largest surface area in Diyarbakur. Logistic regression methods were \\ used in addition to descriptive statistics in the analysis of the data. In the study, it was reported that rural women's environmental awareness \\ is scientifically important at the level of women's diseases (0.003) which dramatically increases environmental awareness by $25.5 \%$. Contrary \\ to the early marriage behaviors of women in rural areas, an increase in one year of marriage is positive and scientifically significant at the \\ level of (0.025), and it increases the environmental awareness by 2.5\%; an increase in the educational level of the husband is $2.2 \%$ effective in \\ the formation of environmental awareness of these women. In addition, it has been determined that women having agricultural activities are \\ scientifically significant for the formation of environmental awareness at a level of (0.046) and the level of religiosity has marginal effect on \\ environmental awareness scientifically. \\ Key words: rural women, environmental knowledge, logistic regression.
}

Determinando os fatores que influenciam a formação da consciência ambiental das mulheres rurais: o caso de Diyarbakır-Erga, Turquia

RESUMO: Neste estudo, pretende-se conhecer os fatores que afetam a consciencia ambiental das mulheres rurais, que constituem a outra metade da sociedade, o que é condição para o desenvolvimento de comportamentos ambientais. Os dados do estudo foram coletados por meio de pesquisa presencial em Ergani, o distrito com a maior área de superfície em Diyarbakır na Turquia. Métodos de regressão logística foram utilizados, além da estatística descritiva na análise dos dados. No estudo, constatou-se que a consciência ambiental das mulheres rurais é cientificamente importante no nível de doenças femininas $(0,003)$ e ter a doença aumenta drasticamente a consciência ambiental em 25,5\%. Ao contrário dos comportamentos de casamento precoce das mulheres nas áreas rurais, um aumento em um ano de casamento é positivo e cientificamente significativo (0,025), e aumenta a consciência ambiental em 2,5\%; o aumento da escolaridade do marido é de $2,2 \%$, efetivo na formação da consciência ambiental dessas mulheres. Além disso, foi determinado que as mulheres com atividades agrícolas são cientificamente mais significativas para a formação da consciência ambiental $(0,046)$ e o nivel de religiosidade tem efeito marginal na consciência ambiental cientificamente.

Palavras-chave: mulheres rurais, conhecimento ambiental, regressão logística.

\section{INTRODUCTION}

It is a well-known fact that human activities are largely responsible for the environmental damage. The air, soil and water pollution experienced today is due to human intervention in nature. Poor air quality and food quality pose a serious risk to human health. Damage to nature mostly occurs through mass production, agricultural or industrial. Particularly in developing countries, many farmers, particularly women, in rural areas are victims of environmental degradation (ŞENGHOR, 1985). In developing countries, environmental problems are related to human health, productivity, and the deterioration of the future efficiency of natural resources that many people depend on directly (KARAER \& GÜRLÜK, 2003). For example, the environmental damage of pesticides used only in agriculture is high (KHAN, 1999; BURNETT, 1990). The main strength of the rural economy and development is women because 
women in developing countries heavily participate in agricultural production activities (YAVUZ et al., 2018). Like every living thing, rural women are users of the environment, they affect the environment, and they are affected by environmental conditions. The way women use the environment typically depends on their traditional gender roles. However, because so many agricultural activities can be done by both women and men, rural women take more responsibility than women and their husbands in the city in terms of production, education, health, food, and nutrition (TALUĞ, 1986). The traditional genderbased distribution of labor happens much less in rural areas, and women provide food and drink for their families and communities by using and managing natural resources (HABLEMİTOĞLU, 1998). Thus, rural women are more affected by environmental damage because the depletion of natural resources and the decrease in agricultural productivity increase the burden of women engaged in agricultural activities producing products and preparing food (ALICA, 2017). A person's awareness, views, and consciousness affect their individual behavior toward the environment. It is likely that individuals who have environmental awareness and consciousness behave in an environmentally friendly manner in each of their activities while continuing their lives (ERKAL et al., 2011). The willingness of individuals to have positive thoughts and take positive actions toward environmental problems can be defined as environmental sensitivity, and this occurs as a result of a certain consciousness (ÇALIŞKAN, 2003).

There is no doubt that there is a parallel between environmental awareness and environmentally sensitive behavior, and many factors that shape environmental awareness (TSCHIDA, 2004). Factors affecting environmental consciousness may differ from country to country according to economic class and gender (AYDIN el al, 2013; YÜCEL et al., 2008).

In this study, the environmental awareness level of individuals living in a rural sector, the Ergani district of the Diyarbakır province was measured, and factors affecting the formation of consciousness and their effect levels were revealed.

\section{MATERIALS AND METHODS}

\section{Materials}

Diyarbakir province is located at $37^{\circ}$ $57^{\prime} 41 \mathrm{~N}$ latitude and $40^{\circ} 13^{\prime} 54 \mathrm{E}$ longitude in the southeast region of Turkey. Ergani is 57 kilometers away from Diyarbakir and is the biggest district of the province in terms of population. The primary material of the study was the data obtained from the Ergani district of Diyarbakır (Figure 1). The reason

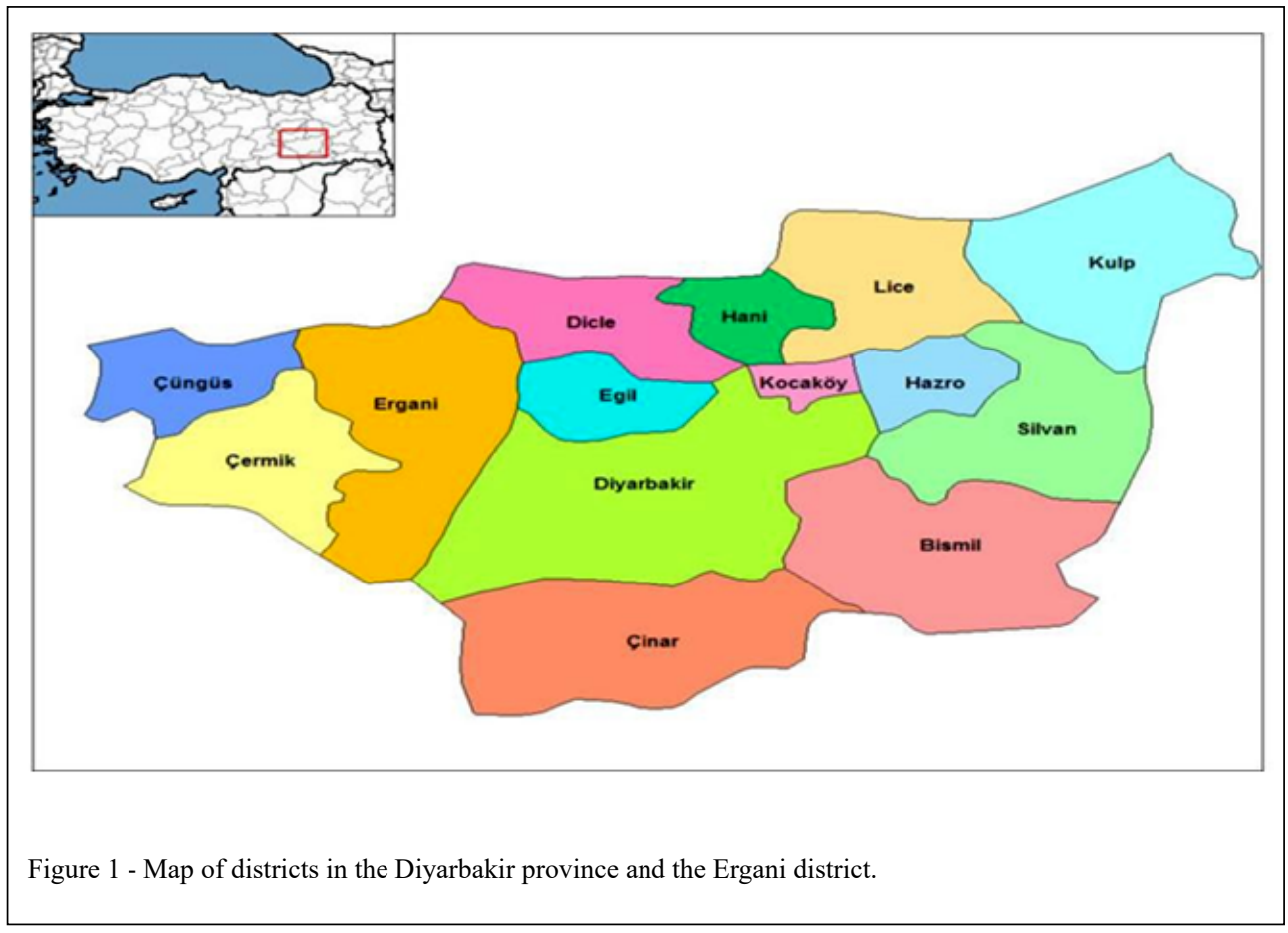

Ciência Rural, v.51, n.6, 2021. 
for choosing Ergani district as the study area was that the district is suitable for vegetative and animal production, but unlike other districts, it has field and backyard vineyards as well as cattle and sheep breeding. In addition; although, it is a district, most of the residents were selected because they work in the agricultural sector.

\section{Methods}

In this study, environmental awareness level of the female population was determinedand conducted in the villages of the Ergani district in Diyarbakir province, the data were collected from face-to-face interviews with married women aged 15 and over. According to the 2017 data from the Statistical Institute, the number of women over the age of 15 living in Ergani district was 42,415. In this study, because the population was colossal, the proportional sampling method was used. A method of sampling in which the investigator divides a finite population into subpopulations and then applies random sampling techniques to each subpopulation. Proportional sampling is similar to a proportional allocation in a finite population sampling, but in a different context, it also refers to other surveysampling situations. For this purpose, the following proportional sampling formula was used (ÇIÇEK \& ERKAN, 1996):

$$
\begin{aligned}
& n=\frac{N p(1-p)}{(N-1) D^{2}+p(1-p)} \\
& D=\frac{d}{Z_{\sigma / 2}}
\end{aligned}
$$

where

$\mathrm{n}=$ sample size,

$\mathrm{N}=$ total number of adult women

$\mathrm{d}=$ deviation from the average $(7 \%)$,

$Z_{\sigma / 2}=95 \% \mathrm{Z}$ scale value for confidence interval (1.96)

$\mathrm{D}=\mathrm{d} / \mathrm{Z}_{\sigma / 2}$

$\mathrm{p}=$ probability of married women included in the sample ( 0.50 was taken to reach the maximum sample volume)

$$
\begin{aligned}
& \left.n=\frac{42415 \times 0.5(1-0,5)}{(42415-1) \times 0.035^{2}+0.5(1-0.5)} \quad \mathrm{D}=\frac{0.07}{1.96}=0.035 \text { (\%95 güven aralı̆̆ }\right) \\
& n=\frac{10603.75}{51.99}=203 \text { married woman }
\end{aligned}
$$

The sample was calculated as 203 women. Considering the possibility of ignoring surveys due to inconsistent data, the calculated sample size was increased by about $23 \%$, and the sample size was calculated as 250 people. All the data were checked, and necessary corrections made before data entry. In data entry, to ensure uniformity, previously prepared sheets were used. The data were analyzed after incorrect data input was checked and corrected. In the analysis of quantitative data, the SPSS computer program was used, and the frequencies (f) and percentages $(\%)$ were calculated.

Logistic regression methods were used in the analysis of the data. In econometric studies, limited dependent variable regression models are used when the dependent variable is qualitative, indicating two states that refer to the presence or absence of an event. In case of the occurrence of an event, the dependent variable takes the value of 1 or zero om cases of nonoccurrence. There may be many independent variables describing the dependent variables (GUJARATI, 1995). Three types of methods are used to predict such models, the linear probability method, the logit method, and the probit method.

In this study, the limited dependent variable regression model and the logit estimation method were used to determine the factors affecting the willingness of the breeders to employ AI (GUJARATI, 1995; AKKAYA \& PAZARLİĞLU, 1998).

$$
P_{i}=\mathrm{E}\left(\mathrm{Y}=1 \mid \mathrm{X}_{\mathrm{i}}\right)=\frac{1}{1+e^{-\left(\beta_{1}+\beta_{2} X_{i}\right)}}
$$

For the ease of illustration, the formula could be shown as follows (Eq. 4):

$$
\begin{aligned}
& P_{i}=\frac{1}{1+e^{-Z_{i}}} \\
& Z=\beta_{1}+\beta_{2} X_{i}
\end{aligned}
$$

The marginal or partial effect measures the effect of (xi) on either the independent variables on the mean of the dependent variable $y$. The marginal effect of an independent $\mathrm{x}$ variable is the partial derivative taken with respect to $\mathrm{x}$ and is equal to the slope coefficient of the independent variable in the linear regression models. This greatly simplifies analysis in such models. However, interpreting the results of regression analysis can be difficult in non-linear models such as interactions, categorical variables, or logistic regression, as used in this study. In such models, it is necessary to see the effect of the independent variables on the dependent variable to interpret the calculated coefficients, in most cases. The calculus and finite difference methods are used in the calculation of the marginal efficiency, and the result is not changed in either method, but the finite difference method gives better results in binary variables (CAMERON \& TRIVEDİ, 2010). In this way, the partial (marginal) effects of independent variables on the dependent variable are calculated according to the finite difference method as in this study. The variables considered in the study are explained in table 2 . before the regression analysis, a correlation analysis was performed to determine the variables to 
be included in the regression analysis. The correlation matrix was measured by a large number of variables. It can be explained as variable statistics that combine the variables associated with each other to measure and describe these variables with a single variable, thus reducing the variable and allowing the structure to be measured in this way (STAPLETON, 1997).

Respondents were asked about their first three engagements, and, according to the answers, the participation of the rural women in the farm work as part of the labor force was derived. For this purpose, activities related to farm work were coded as 1 while the nonagricultural activities were coded as 0 . Then, the first rank, second rank, and third rank activities were multiplied by 3,2 , and 1 , respectively, and the results were summed up for each respondent. The new values that ranged from 0 to 6 were recoded as 0 , 1 , and 2 as $0-2$ to $0 ; 3-4$ to 1 ; and 5-6 to 2 , indicating non-or weak participation, moderate participation and high participation, respectively table 1 .

The aggregate index was calculated for participating in the rural women in the farm work as part of the labor force. For this purpose, first-, second-, and third-ranked activities were made to speak a single language through multiplying the first rank by three, the second rank by two, and the third rank by one. Then, they were all summed up and put in order. Later, the values between 0 and 2 were coded into 0,3 , and 4 into 1 , and 5 and 6 into 3, indicating that 0 equaled nonparticipation, 1 equaled moderate participation, and 2 equaled high participation.

\section{DISCUSSION AND CONCLUSION}

\section{Socio-economic characteristics}

All those included in the research are women and married. The age of women in the study was between 18 and 68 years old, and the mean age was 36.4 years. The fact that the use of physical workforce in agricultural production is more intense than other sectors makes age an important factor in agricultural production activities. In addition, the examination of women by age is important in terms of revealing the relationships between age and other qualifications (YILDIRAK, et al., 2003) The mean age of women participating in agricultural production activity varies from region to region. For example, it was determined as 40.36 (KUTLAR et al., 2013) in Burdur, 31.7 (PAL \& HALDAR, 2016) in India and 38.98 (FARID et al., 2009) in Bangladesh.

Examining women in terms of education is important for revealing the relationships between education and other qualifications. Because, education contributes economically and socially to the development of rural residents, (HUNDER, 1969). It was observed that $39.8 \%$ of rural women included in the scope of this research are not educated at all, $12.4 \%$ are literate, and $29.9 \%$ are primary school graduates. In other words, $82.1 \%$ of women were found to have

Primary or lower education. In a study by YAVUZ et al. in Erzurum at a near place and time, $77.5 \%$ of women have primary and lower education (YAVUZ et al. 2018). Education levels of spouses in the marriage union are undoubtedly an important factor in terms of affecting each other. In the study, it was observed that $55 \%$ of the husbands of rural women had primary and lower education, and $44.6 \%$ of them had secondary and higher education.

An important indicator that reveals the socio-cultural levels of societies is the age of marriage. It was determined that it is smaller in Central Anatolia and Eastern regions, and there is a positive relationship between the level of education and marriage age. Marriage age of urban Turkish women was found to be higher than the ones those living in rural areas; marriage age in the Central Anatolian and eastern regions is smaller and there is a positive relationship between the age of marriage and education level (ANONYMOUS, 2018). It was observed that marriage age of the women in the study was 11 as minimum and 30-maximum; the mean age of marriage was 18.54 , and the region was compatible with the mean rural age of marriage. Knowing the population structure of rural enterprises is important in terms of the effectiveness of the workforce and revealing socio-economic and socio-cultural characteristics. While the maximum number of children in the study was 12 , the average number of children was 4 , and the average population per household was determined as 6 . According to the demographic data of 2019, while the average population per household in Turkey is 3.4, the average population of the Southeastern Anatolia, where the study was conducted, is 4.7 (ANONYMOUS, 2019). In the study by ŞAHIN \& TERIN in 2008 in the rural area of Van province, which is similar to the field of study, the average number of children per family was 5.5 (ŞAHIN \& TERIN, 2009). It has been determined that $70.5 \%$ of the women in the study live in the village, $19.5 \%$ in the district center, $10 \%$ live in both in certain times of the year. This parameter showed that the women in the sample meet the rural women profile. In this study $64.1 \%$ of the women stated that they did not have a health problem and $35.9 \%$ stated that they had a health 
Table 1 - Derivation of the rural women's participation to farm work as part of the labor force.

\begin{tabular}{|c|c|c|c|c|c|c|c|}
\hline Respondents & Top three Engagements & Answers & Coding & Multiplied by & Equalling & Total Score & Recoding \\
\hline \multirow{3}{*}{1} & First & Hoeing & 1 & 3 & 3 & \multirow{3}{*}{5} & \multirow{3}{*}{2} \\
\hline & Second & Milking & 1 & 2 & 2 & & \\
\hline & Third & House cleaning & 0 & 1 & 0 & & \\
\hline \multirow{6}{*}{2} & First & Child caring & 0 & 3 & 0 & \multirow{3}{*}{3} & \multirow{3}{*}{1} \\
\hline & Second & Milking & 1 & 2 & 2 & & \\
\hline & Third & Hoeing & 1 & 1 & 1 & & \\
\hline & First & Child caring & 0 & 3 & 0 & \multirow{3}{*}{1} & \multirow{3}{*}{0} \\
\hline & Second & Cooking & 0 & 2 & 0 & & \\
\hline & Third & Hoeing & 1 & 1 & 1 & & \\
\hline
\end{tabular}

Total scores that range between 0 and 6 were recoded into 0,1 and 2 as 0 to $2 ; 3-4$ to 1 and $4-6$ to 2 , indicating non or weak participation, moderate participation and high participation respectively.

problem. We observed that the most common three diseases of women with health problems were high blood pressure, thyroid and asbestos-related diseases, respectively. The second most important disease is various thyroid diseases caused by imbalances in the use of iodine. The Endocrinology and Metabolism Association in Turkey (ANONYMOUS, 2008) noted that the iodine deficiency is prevalent in rural areas. Ergani district is a common place, in which Asbestos mineral powders that are known as asbestos among the people are the cause of many respiratory diseases due to environmental factors (KONUKSEVER, 2014).

\section{Regression analysis result}

The research determined the environmental consciousness of women living in rural areas of the Ergani district and the factors affecting the consciousness of conscious women. It was observed that $42.7 \%$ of women in the study were conscious, and $57.3 \%$ were unconscious. Consciousness was taken as a dependent variable, and a logistic regression analysis was performed (Table 2). This dependent variable has been tested with eleven independent variables. In addition, the marginal (partial) effect was calculated to see the effect of independent variables on the dependent variable.

According to the results of the regression analysis, a negative but insignificant relationship was determined between the age of manufacturer and their idea of continuing organic agriculture. Increasing the age of women by 10 years reduces the probability of an increase in environmental awareness by only a small percentage of $1 \%$ (Table 2). According to some researchers, it is stated that there is an important relationship between environmental awareness and ages of individuals (VAN LIERE \& DUNLAP,
1981; BALDERJAHN 1988; BUİ, 2005). There is a positive but meaningless relationship between women's education and environmental awareness. Since women in rural areas are more male-dominated and dependent on men than women in cities, the age of the spouse is taken as an independent variable. No scientifically meaningful relationship was reported between the husband's age and the woman's environmental awareness. For the same reasons above, the education level of the husband was taken as an independent variable, and a positive and scientifically (0.047) significant relationship was reported between them. In other words, an increase in the husband's (spouse's) education year by 1 unit increases the level of awareness of women by $2.2 \%$. According to this result, it is thought within the scope of this research that power and dominance of men are high in the social structure. Another independent variable that is thought to affect women's environmental awareness is total annual income. Because, as the income level increases, it is thought that the probability of individuals starting to deal with other issues besides their mandatory needs will increase. However, it has been observed that the relationship between awareness and income levels of the women in the research is positive, but the relationship is unscientific ally meaningful. In a similar study, it was determined that there is not much difference in environmental issues in terms of sensitivity among different farmers (KIZILASLAN \& KIZILASLAN, 2005). In another study, it was observed that environmental awareness increased as the income group increased (YILMAZ, 2009). An indicator of rural behavior and sociocultural structure in rural areas is the age of marriage. For example, 
Table 2 - Logistic regression analysis results.

\begin{tabular}{|c|c|c|c|c|c|}
\hline Independent variables & Coef. & Robust Std Err. & $\mathrm{z}$ & $\mathrm{p}>$ ItI & Marginal effect (dy/dx) \\
\hline Age & -0.005 & 0.012 & -0.41 & 0.681 & -0.001 \\
\hline Schooling & 0.047 & 0.055 & 0.87 & 0.387 & 0.009 \\
\hline Spouse age & 0.006 & 0.022 & 0.27 & 0.789 & 0.001 \\
\hline Schooling & 0.112 & 0.056 & 1.99 & $0.047^{* *}$ & 0.022 \\
\hline \multicolumn{6}{|c|}{ 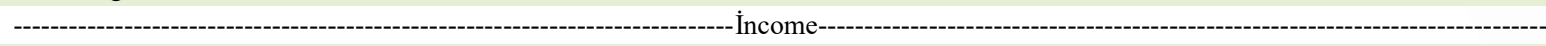 } \\
\hline 1 & 0.151 & 0.393 & 0.38 & 0.701 & 0.029 \\
\hline 2 & 0.686 & 0.518 & 1.32 & 0.186 & 0.139 \\
\hline Age at marriage & 0.126 & 0.056 & 2.24 & $0.025^{* *}$ & 0.025 \\
\hline \multicolumn{6}{|c|}{ 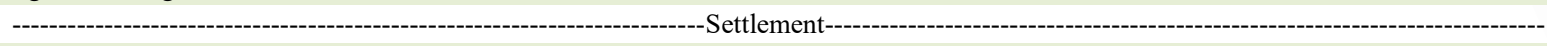 } \\
\hline 2 & 0.505 & 0.432 & 1.17 & 0.242 & 0.104 \\
\hline 3 & 0.912 & 0.524 & 1.74 & $0.082^{*}$ & 0.190 \\
\hline No of child & -0.057 & 0.113 & -0.50 & 0.615 & -0.011 \\
\hline H problem & 1.313 & 0.442 & 2.97 & $0.003^{* *}$ & 0.255 \\
\hline \multicolumn{6}{|c|}{ - } \\
\hline 1 & -0.008 & 0.385 & -0.02 & 0.982 & -0.011 \\
\hline 2 & 0.867 & 0.433 & 2.00 & $0.046^{* *}$ & 0.179 \\
\hline Faith degree of & 1.212 & 0.649 & 1.86 & $0.062^{*}$ & 0.022 \\
\hline _cons & -5.528 & 1.837 & -3.01 & 0.003 & \\
\hline
\end{tabular}

Log pseudolikelihood:-128.84769.

$\mathrm{dy} / \mathrm{dx}$ is the discrete change of dependent variable when independent dummy variable shifts from 0 to 1 .

${ }^{* *} \mathrm{p}<0.05{ }^{*} \mathrm{p}<0.010$.

MALHOTRA \& TSUI (1996), who are among the ones with studies linking early marriage with the modernization process, stated that family and cultural factors played an important role in determining the age of marriage despite the impact of modernization. In this study, it has been concluded that the age of marriage gradually increases with the modernization of Sri Lanka and the changing roles within the family and the school attendance of girls (BURCU et al., 2015). For this reason, the marriage age of rural women was taken as an independent variable, and its relationship with environmental awareness was questioned. A statistically significant and positive relationship (0.025) was reported between environmental awareness and age of marriage (Table 2). In other words, the increase in marriage age by one year increases environmental awareness by $2.5 \%$. The place of residence, which is one of the variables that may affect environmental awareness, was taken as a categorical variable. It has been determined that living in the village or city does not have a statistically significant effect on environmental awareness, but living both in the village and city in certain times of the year has a positive and marginally significant (0.082) impact on environmental awareness (Table 2).
Childcare is mostly synonymous with women due to their maternal qualities, but because the number of children in rural areas is higher than the cities, women's obligation for children is higher. Unlike their spouses, women engaged in agricultural activities in rural areas also increase their daily working hours because they take care of children (KIZILGÖL, 2012). It is expected result that the high responsibilities of women will impact their socio-cultural development. Therefore, the number of children was taken as a variable in the study. It has been observed that there is a negative relationship between the number of children and environmental awareness, but this relationship is unscientifically meaningful. Since the relationship between the environment and human health is an undeniable reality, when the relationship between the health problem and environmental awareness is examined, it is seen that there is a positive, statistically and highly significant (0.003) relationship between environmental awareness and health problems. In other words, health problems increase environmental awareness by $25.5 \%$. In the relationship between whether women are engaged in agricultural activities and their environmental awareness, participation 
in agricultural activity has a positive, statistically significant and strong relationship with environmental awareness. As a socio-cultural institutions that affects the individual and society, religion is one of the factors that guide the behavior of people in their daily lives (PEKER, 1990; ÜNAL, 2010). For this reason, religiosity is considered a variable and there is a positive, and marginally significant relationship between religiosity and environmental awareness.

It is people who pollute the nature, and the people who will clean it must first have their own mentality clean. In other words, in order for humans to create an environmentally sensitive attitude, the awareness that they will develop on the environment must first be formed, that is, attitude and behavior will not develop before awareness is formed. Efforts to increase production in conventional agriculture today lead to disruption of natural balance, environmental pollution, life threats and genetic erosion in humans, plants and animals. Before the irreversible destruction of nature and environment, people have a chance because nature and environment can renew themselves if people allow it. What needs to be done in this context is to create "environmental awareness." Considering the familial role, responsibilities and contribution of women, who make up half of the society or rural society, in their children's education, how crucial the environmental awareness of rural women is to the world should be acknowledged.

Social structure in Turkey is in a passive position politically. Rural women are more passive in this social structure. In the study, the fact that the education level of the woman does not affect environmental awareness scientifically, and the increase in the environmental awareness of the husband's education confirm this situation. When considered from this perspective, it is thought that the determination and sensitivity of policy makers regarding environmental protection measures and nature improvement measures will affect the society. In this study, it has also been seen that education levels of men in rural areas are higher than women, and again it has been seen that men play an important role in creating environmental awareness in women. This situation can be interpreted in different ways. As seen in this study, the education level of men in rural areas is higher than women, and it is seen that environmental awareness increases in men with higher education and this situation affects their partners. Or, environmental awareness is provided within the education system in later years, and because women receive little education, they cannot have environmental awareness. For this reason, while a scientifically meaningful relationship cannot be established between women's environmental awareness and education level, environmental awareness of rural men increases since they receive more education than women in any case and this affects women's environmental awareness. The result in both cases is as follows: Although, it is extremely important to ensure that rural women receive education as much as men, it is considered vital to start environmental awareness education before the preschool education period.

The awareness of women living in the city as well as in the village in certain months of the year was found to be scientifically positive and meaningful. The reason for this is interpreted as that decreasing awareness of women constantly living in the village or district stems from the fact that they are accustomed to the conditions they live in. It is thought that individual's experience of different living areas is important in terms of gaining perspective. As it is not possible to provide women with living space alternatives in this regard, it is considered that it will be beneficial to create environmental awareness for girls, especially in secondary school and high school education. Experiencing the district and village together throughout their education life will contribute to the creation of environmental awareness. Due to their daily work and responsibilities, rural women only leave their village soon to go to the hospital or doctor. It is thought that it will be beneficial to inform women, who have become sensitive due to their illness, in the health centers, even in short periods. It is thought that it would be beneficial to provide information on environmentally originated asbestosrelated diseases, which are common in the region, and that many diseases may be of environmental origin. Although, women gain the title of manufactures even only with their gender, environmental relationships and commitment of women, who are engaged in agricultural production activities in rural areas, increase, and their environmental awareness and sensitivity are high since they earn their living from agriculture. This result was clearly observed in the regression analysis. For this reason, it is considered important to promote social security subsidies and credit opportunities by making them advantageous for women to continue to take part in production in rural areas. In urban areas, it is thought that it will be beneficial to guide women with television and social media on "balcony farming, pot and hobby gardening" to increase their contact with nature and raise environmental awareness. Since religiousness and conservatism are higher in rural areas than in urban areas and it affects environmental consciousness 
positively and scientifically meaningfully, it is thought that it will be effective to indicate the importance of the subject in informative khubtahs.

It should not be forgotten that the environment is an important area of social responsibility. Therefore, women and others cannot be expected to acquire this behavior in the normal course of their lives. For this, environmental awareness should be supported by the strict implementation of legal practices. Environment and sustainable agriculture should be prioritized in agricultural extension trainings. It should not be forgotten that nature does not need us, humans need nature. As we now see, nature does not hesitate to remind us of this immutable truth.

\section{ACKNOWLEDGEMENTS}

This work was not supported by any institution. We would like to thank the families who patiently answered us in the survey applications.

\section{DECLARATION OF CONFLICT OF INTERESTS}

The authors declare no conflict of interest. The founding sponsors had no role in the design of the study; in the collection, analyses, or interpretation of data; in the writing of the manuscript, and in the decision to publish the results.

\section{AUTHORS' CONTRIBUTIONS}

The entire article was written by one author.

\section{REFERENCES}

ANONYMOUS.A. 2020. Turkısh Statistical Instıtute. Available from: $\quad<$ https://biruni.tuik.gov.tr/bolgeselistatistik/tabloOlustur. do>. Accessed: Feb. 28, 2019.

ANONYMOUS. B. 2008. Hacettepe Üniversitesi Nüfus Etütleri Enstitüsü Araştırması. Available from: <http://www.hips. hacettepe.edu.tr/tnsa2018/rapor/sonuclar_sunum.pdf $>$. Accessed: Feb. 28, 2019.

AKKAYA, S., PAZARLIOĞLU, M. V. 1998. Econometrics II. Erkam Publishers, İstanbul. Available from: $<$ https://dergipark. org.tr/tr/pub/ije/article/638391>. Accessed: Feb. 10, 2019.

ALICA, S. G. 2017. Woman And Environment. Union of Turkish Bar Association Review, Special Issue: 151-172. Available from: <http://tbbdergisi.barobirlik.org.tr/m2017-20171719>. Accessed: May, 19, 2019.

AYDIN, F., ÜNALDI, E. 2013. Coğrafya Öğretmen Adaylarının Sürdürülebilir Çevreye Yönelik Tutumları. Kalem Eğitim ve İnsan Bilimleri Dergisi, 3(1):11-42. Available from: <https:// dergipark.org.tr/tr/pub/nwsaedu/issue/19843/212569>. Accessed: May, 21, 2019.
BALDERJAHN, I. 1988. Personality Variables and Environmental Attitudes as Predictors of Ecolog ically Responsible Consumption Patterns. Journal of Business Research, 17 (1): 51-56. Available from: <https://www.sciencedirect. com/science/article/abs/pii/0148296388900227>. Accessed: Jan. 21, 2020.

BUI, M. H. 2005. Environmental Marketing: A Model Of Consumer Behaviour. Proceedings of the Annual Meeting of the Association of Collegiate Marketing Educators, New Orleans, pp.22 -28. Available from: <http://libroweb.alfaomega.com.mx/ book/733/free/ovas_statics/unid3/PDF_Ingles/Environmental_ Marketing.pdf $>$. Accessed: Nov. 21, 2019.

BURCU, E., YILDIRIM, F., SIRMA C.. S., SANIYAMAN, S. 2015. Fate of the Flowers: A Qualitative Research on Early Marriage of Turkish Women. Bilig (Journal of Ahmet Yesevi Uninersty), 1(73): 63-98. Available from: <https://avesis. hacettepe.edu.tr/yayin/b4ab5a6e-207c-4857-be98-107209495d38/ fate-of-the-flowers-a-qualitative-research-on-early-marriage-ofturkish-women>. Accessed: Dec. 12, 2019

BURNETT, J. 1990. Ecology, Economics And The Environment. The Royal Bank of Scotland Review, 167(1):315. Available from: <https://www.cabdirect.org/cabdirect/ abstract/19901895073>. Accessed: Dec. 24, 2019.

CAMERON, A. C., TRIVEDİ, P. K. 2010. Microeconometrics Using Stata. Revised ed. Stata Press, College Station, TX.

ÇALIŞKAN， M. 2003. Yetișkinlerde Cevre Duyarlılığını Etkileyen Etmenler. Ankara Üniversitesi, Eğitim Bilimleri Enstitüsü, Yayımlanmamış Yüksek Lisans Tezi, Ankara. Available from: <https://tez.yok.gov.tr/UlusalTezMerkezi/ tezSorguSonucYeni.jsp>. Accessed: Dec. 15, 2019.

ÇIÇEK, A. VE ERKAN, O. 1996. Tarım Ekonomisinde Araştırma ve Örnekleme Yöntemleri. Gaziosmanpaşa Üniversitesi Ziraat Fakültesi Yayınları, No:12, Tokat.

ERKAL, S., et al. 2011. Sürdürülebilir Kalkınma ve Çevre Bilincinin Oluşturulmasında Ailenin Rolü. Sosyo Ekonomi, 14(1):146. Available from: <https://studylibtr.com/doc/1889226/ s\%C3\%BCrd\%C3\%BCr\%C3\%BClebilir>. Accessed: Jan. 13, 2020.

FARID, K. S., e al. 2009. Nature And Extent Of Rural Women's Participation İn Agricultural And Non-Agricultural Activities. Agricultural Science Digest, 29(4): 254-259. Available from: <https://d1wqtxts1xzle7.cloudfront.net/37427053/ Nature_and_extent_of_rural_womens_participation_in_ agricultural_>. Accessed: Jan. 10, 2020.

GUJARATİ, D. N. 1995. Basic Econometrics. Mc Graw-Hill, USA.

KARAER, F., GÜRLÜK, S. 2003. The Agr1-EnvironmentEconomic Relationshıps In The Developıng Countries. Jounal of Doğuş Universty, 4 (2):197-206. Available from: <https:// www.researchgate.net/publication/279464067_Gelismekte_Olan Ulkelerde Tarim - Cevre - Ekonomi Etkilesimi>. Accesse $\overline{\text { d: }}$ Dec. 11,2019

HABLEMITOĞLU, Ş. 1998. Kırsal Alanda Kadın: Sorunlar ve Yaklaşımlar. Kalkınmada Anahtar, MPM Aylık Yayın Organı, 10, (112):98-100. Available from: <https:// scholar.google.com/scholar?hl=tr\&as_sdt $=0,5 \&$ clust er $=10722126177132945741>$. Accessed: Dec. 13. 
HUNDER, G. 1969. Modernizing Peasant Societies, A Comparative Study in Asia and Africa. Oxford University Press, London. Available from: <https://scholar.google.com.tr/ scholar? $\mathrm{q}=$ Modernizing + Peasant + Societies,$+\mathrm{A}+$ Comparative + Study + in + Asia + and\&hl $=$ tr\&as_sdt $=0 \&$ as_vis $=1 \&$ oi $=$ scholart $>$. Accessed: Nov. 24. 2019

MALHOTRA, A., TSUI, A. O. 1996. Marriage Timing in Sri Lanka: The Role of Modern Norms and Ideas. Journal of Marriage and Family, 58(2): 476-490. Available from: $<$ https:// scholar.google.com.tr/scholar?hl=tr\&as $\mathrm{sdt}=0 \% 2 \mathrm{C} 5$ \& as vis $=1 \&$ $\mathrm{q}=.+$ Marriage + Timing + in + Sri + Lanka $\% 3 \mathrm{~A}+$ The + Role + of + -Moder $\mathrm{n}+$ Norms + and+Ideas. $+\&$ btnG=>. Accessed: Nov. 16, 2019.

KIZILASLAN, H., KIZILASLAN, N. 2005. Rural Public Awareness Level And Behavior In Environmental Matters (Example Of Artova District Of Tokat). Journal of ZKU Social Sciences, 1(1): 68-86. Available from: <http://ijmeb.org/index. php/zkesbe/article/view/100>. Accessed: Dec. 10, 2019.

KIZILGÖL,A. Ö. 2012. The Determınants Of Female Partıcıpatıon To The Labour Force: An Econometric Analysıs. Journal of Doğus Universty, 13 (1): 88-101. Available from: <http://journal.dogus. edu.tr/index.php/duj/article/view/281>. Accessed: Jul. 03. 2019

KONUKSEVER, Ü. 2014. Mineral Dusts And Their Environmental Effects: A Case Study From Ergani (Diyarbakır). 2014. 52f. Harran University Graduate School of Natural and Applied Sciences Department of Environmental Engineering, MSc Thesis, Available from: <https://tez.yok.gov.tr/UlusalTezMerkezi/ tezSorguSonucYeni.jsp>. Accessed: Jul. 02, 2019.

KUTLAR, İ., KIZILAY, H., TURHANOĞULLARI, Z. Kırsal Alanda Kadınların İşgücüne Ve Kararlara Katılımını Etkileyen Sosyoekonomik Faktörlerin Belirlenmesi: Burdur İli Örneği. Akdeniz Üniversitesi Ziraat Fakültesi Dergisi, v.26, n.1, p.27-32, 2013. Available from: <https://dergipark.org.tr/tr/pub/ akdenizfderg/issue/1564/19386>. Accessed: Jul. 02, 2019.

PAL, S., HALDAR, S. Participation and role of rural women in decision making related to farm activities: A study in Burdwan district of West Bengal. Economic Affairs, v.61, n.1. p.5563, 2016. Available from: <https://www.researchgate.net/ publication/301738300_Participat>. Accessed: Jul. 01, 2019.

PEKER, H. Suçlularda Dini Davranışlar. Ondokuz Mayıs Üniversitesi İlahiyat Fakültesi Dergisi, v.1990, n.4, p.93-123, 1990. Available from: <https://dergipark.org.tr/tr/pub/omuifd/ issue/20311/215673>. Accessed: Jun. 30. 2019.

ÜNAL, V. 2010. İslam'da İbadetlerin Sosyal Fonksiyonu. Cumhuriyet Üniversitesi İlahiyat Fakültesi Dergis, v.14, n.1, p.355-370, 2010. Available from: <https://dergipark.org.tr/tr/ download/article-file/51592>. Accessed: Jun. 30, 2019.
SENGHOR, D. Feminism And Environmentalism: In a Candle Light. İn Ecoforum, v.10, n.2, p.181, 1985.

STAPLETON, C. D. Basic Concepts and Procedures of Confirmatory Factor Analysis. Paper presented at the Annual Meeting of The Southwest Educational Research Association. 1997. Available from: <https://files.eric.ed.gov/fulltext/ED407416. pdf $>$. Accessed: Oct. 01, 2019.

ŞAHIN, K., TERINN, M. Participation in Agricultural Activities and Opinion on Agricultural Extension of Women in Two Villages Differing Socio-Economically in Van Province. Akdeniz Unıversity Faculty of Agriculture Journal, v.22, n.1, p.39-49, 2009. Available from: <https://dergipark.org.tr/tr/ pub/akdenizfderg/issue/1572/19474>. Accessed: Sep. 07, 2019.

TALUĞ, C. Kırsal Alanın Unutulan Üreticileri: Köylü Kadınlarımız. Ankara: Türkiye Endokrinoloji ve Metabolizma Derneği Metabolik Sendrom Kılavuzu, 1986. 121p.

TSCHIDA, D. A. The Crocodile Hunter, The Jeff Corwin Experience and the Construction of Nature: Examining the Narrative and Metaphors in Television's in Environmental Communicatio. 2004.12f. PhD, Missouri- Columbia University. Available from: <https://books.google.com.tr/books?id=v9FqDw AAQBAJ\&pg=PA241\&lpg=PA241\&dq $=\mathrm{TSCH} \% \mathrm{C} 4 \%$ B0DA, $+\mathrm{D}$ .A. $+200>$. Accessed: Sep. 15, 2019.

VAN LIERE, K. D., DUNLAP, R. E. Environmental Concern Does İt Make A Difference How İt's Measured. Environment \& Behaviour, Washington State, v.13, n.6, p.651-676, 1981.

YAVUZ, F., et al. An Analysis on Women Participation in Agricultural Production Activities: Case of Northeast Anatolia TRA1 Region. Turkish Journal of Agricultural Economics, v.24, n.2, p.185-192, 2018. Available from: <https://Journal. tarekoder.org/tr/pub/tr/issue/38802/474478>. Accessed: Sep.19. 2019.

YILDIRAK, N., et al. 2003. Türkiye'de Gezici ve Geçici Kadın Tarım İşçilerinin Çalışma ve Yaşam Koşulları ve Sorunları. Ankara: Tarım-İ̧ Sendikası Yayınları, 2003. 57p.

YILMAZ, R. Investigation on The Environmental Consciousness Level in Edirne and Its Relations with Socio-Economic Structures. Journal of Tekirdag Agricultural Facult, v.6, n.1, p.69-92, 2009. Available from: <https://dergipark.org.tr/tr/download/articlefile/416335>. Accessed: Jan. 10, 2020.

YÜCEL, M., et al. Adana'da Halkın Çevre Duyarlılığının Saptanması ve $\mathrm{Bu}$ Duyarlılı̆g Arttırabilecek Önlemlerin Geliştirilmesi. Adana Kent Sorunları Sempozyumu, Adana, v.31, p.364-382, 2008. Available from: <https://dergipark.org.tr/tr/pub/ akdenizfderg/issue/1577/19559>. Accessed: Apr. 08, 2020. 